\title{
Conservatrix: afwikkeling van verzekeraars in de praktijk
}

\section{Lessen uit de Conservatrix-uitspraak en de Wet herstel en afwikkeling verzekeraars}

\author{
Mr. B. Biermanen mr. P. Kerckbaert*
}

\section{Inleiding}

\subsection{Verzekeraars in de problemen}

Nederlandse verzekeraars hebben het over het afgelopen decennium financieel niet eenvoudig gehad. Zo bleek uit recent statistisch onderzoek van De Nederlandsche Bank N.V. (DNB) dat het premievolume (dus de inkomsten) van levensverzekeraars in de periode 2008-2018 meer dan gehalveerd is (van $€ 26,7$ miljard naar $€ 12$ miljard per jaar). Voor schadeverzekeraars is het premievolume in dezelfde tien jaar met $33 \%$ afgenomen (van $€ 20,9$ miljard naar $€ 14,1$ miljard per jaar). ${ }^{1}$ Verder zorgt onder andere de aanhoudend lage marktrente voor lagere kapitaalbuffers. ${ }^{2}$

Een aantal verzekeraars is de afgelopen jaren dan ook (bijna) in de problemen gekomen. Denk aan SNS Reaal in 2013, Vivat (opvolger van SNS Reaal) in 2015, Delta Lloyd in 2016 en - zeer recent - in oktober 2019 Yarden. Al deze grote verzekeraars vonden - al dan niet onder enige druk van DNB een nieuwe eigenaar.

Datzelfde gold in 2017 voor de veel kleinere Baarnse levensverzekeraar Nederlandsche Algemeene Maatschappij van Levensverzekering Conservatrix N.V. (hierna: Conservatrix). In dat geval gebruikte DNB - voor de eerste keer sinds de introductie ervan in 2012 - de toenmalige 'overdrachtsregeling'. Daardoor werd Conservatrix van rechtswege, voor $€ 1$, overgedragen aan een grote Amerikaanse verzekeraar. In feite onteigende DNB daarmee de aandelen van de oude aandeelhouder van Conservatrix, Conservatrix Groep SARL (hierna: Conservatrix Groep). Deze vocht de aantasting van haar eigendomsrechten als gevolg van de overdrachtsregeling aan tot aan de Hoge Raad. Die deed op 17 mei 2019 uitspraak. ${ }^{3}$

* Mr. B. Bierman is advocaat bij Finnius te Amsterdam en is daarnaast verbonden als visiting faculty aan het Hazelhoff Centre for Financial Law van de Universiteit Leiden. Mr. P. Kerckhaert is advocaat bij Finnius te Amsterdam.

1. Zie DNB Statistisch Nieuwsbericht: 'Premievolume Nederlandse levensverzekeraars daalt tot EUR 12 miljard in 2018', 7 juni 2019

2. DNBulletin: 'Stresstest toont kwetsbaarheden Europese verzekeraars', 14 december 2018.

3. HR 17 mei 2019, ECLI:NL:HR:2019:746, NJ 2019/389 m.nt. V.P.G. de Serière. Zie o.a. ook JOR 2019/189 m.nt. E.P.M. Joosen.

\subsection{Afwikkeling}

Op grond van de Wet op het financieel toezicht (Wft) richt het prudentiële toezicht zich op het waarborgen van de soliditeit van financiële ondernemingen, zoals verzekeraars, en de stabiliteit van het financiële stelsel. ${ }^{4}$ De prudentiële toezichthouder, DNB, heeft dan ook onder meer tot taak om op doorlopende basis prudentieel toezicht uit te oefenen op verzekeraars. Dit om te voorkomen dat zij niet langer financieel solide zijn. ${ }^{5}$ Dat doorlopende toezicht heeft alleen niet altijd het beoogde resultaat. In het geval dat een verzekeraar in zwaar weer raakt en daar niet uit komt, kan het de taak van DNB zijn deze verzekeraar op een ordentelijke manier af te wikkelen. ${ }^{6}$ Dit om grotere schade aan polishouders en het financiële stelsel te voorkomen.

De afwikkelingsinstrumenten die DNB voor verzekeraars tot haar beschikking heeft, waren tot voor kort nogal versplinterd. Zo kende de Wft onder andere een opvangregeling, ${ }^{7}$ een noodregeling, ${ }^{8}$ een onteigeningsregeling ${ }^{9}$ en dus de overdrachtsregeling. ${ }^{10}$ De overdrachtsregeling werd in 2012, naar aanleiding van de kredietcrisis, voor banken en verzekeraars in de $\mathrm{Wft}$ geïntroduceerd door middel van de zogenoemde Interventiewet. ${ }^{11}$

Voor banken heeft deze overdrachtsregeling niet lang bestaan. Door de gevolgen die het falen van banken internationaal had voor de reële economie, de belastingbetaler en de euro is er in 2015 door middel van een Europese richtlijn één enkele geharmoniseerde herstel- en afwikkelingssystematiek voor banken geïntroduceerd: de Bank Recovery and Resolution Directive

4. Art. 1:24 lid $1 \mathrm{Wft}$

5. Art. 1:24 lid $1 \mathrm{Wft}$.

6. Art. 1:24 lid $1 \mathrm{Wft}$.

7. Art. 3:151 lid 1 (oud) Wft.

8. Art. 3:160 lid 1 (oud) Wft.

9. Art. $6: 2 \mathrm{Wft}$.

10. Art. 3:159a e.v. (oud) Wft.

11. Wet van 24 mei 2012 tot wijziging van de Wet op het financieel toezicht en de Faillissementswet, alsmede enige andere wetten in verband met de introductie van aanvullende bevoegdheden tot interventie bij financiële ondernemingen in problemen (Wet bijzondere maatregelen financiële ondernemingen), Stb. 2012, 241. 
(BRRD). ${ }^{12}$ De BRRD is per 26 november 2015 geïmplementeerd in de Wft en de Faillissementswet $(\mathrm{Fw}) .{ }^{13}$ Deze implementatiewetgeving kwam - ten aanzien van banken - in de plaats van de oude afwikkelingsregelgeving uit de $\mathrm{Wft}^{14}$

Voor verzekeraars is er op Europees niveau echter (nog) geen met de BRRD vergelijkbaar herstel- en afwikkelingskader geregeld. Dat is ook grotendeels logisch, nu de impact van het falen van verzekeraars in beginsel minder gevoeld is dan dat bij banken het geval was. ${ }^{15}$ Immers, een bank bewaart het geld van het publiek, en bij een faillissement van die bank valt dat geld in de failliete boedel. Een klant kan dan in principe niet bij zijn geld. Bij een faillissement van een verzekeraar kan die hoogstens in de toekomst geen uitkeringen doen, mocht een verzekerde gebeurtenis zich voordoen. Een klant is dan alleen maar de betaalde premies kwijt. Ook is daarmee bij een verzekeraar het risico op een 'bankrun', zoals men dat bij een bank ziet, niet (of in elk geval minder) reëel.

Op nationaal niveau vond de wetgever echter dat de versplinterde afwikkelingsregelgeving voor verzekeraars niet voldeed. Op 1 januari 2019 trad dan ook de Wet herstel en afwikkeling verzekeraars (Whav) in werking, middels wijziging van onder meer de Wft. ${ }^{16}$ De Whav is geïnspireerd op de BRRD voor banken. Daarmee kwam de eerdergenoemde overdrachtsregeling te vervallen. Dus nog voor de Hoge Raad in de Conservatrix-casus een uitspraak had gedaan over de werking van deze overdrachtsregeling was deze alweer ingetrokken. De vraag is of de Conservatrix-uitspraak daarmee van alle relevantie is ontdaan. Wij menen van niet.

\subsection{Opzet artikel}

In dit artikel onderzoeken wij de Conservatrix-casus en vragen wij ons af of er, na de introductie van de Whav, nog lessen uit deze zaak te trekken zijn. Hoe zullen verzekeraars onder de huidige Whav-afwikkelingsinstrumenten worden afgewikkeld, welke vrijheid heeft DNB in dat kader, en hoe zal een rechter de besluiten van DNB toetsen?

12. Richtlijn 2014/59/EU. In het kader van de Europese bankenunie heeft deze systematiek ook een geharmoniseerde component, de Single Resolution Mechanism Regulation (Verordening (EU) 806/2014), die de afwikkelingsmechanismen uit de BRRD direct van toepassing verklaart op significante banken. Deze significante banken hebben ook een centrale afwikkelautoriteit, de Single Resolution Board.

13. Implementatiewet Europees kader voor herstel en afwikkeling van banken en beleggingsondernemingen, Stb. 2015, 431.

14. Zie over bankresolutie en de relatie met nationaal (insolventie)recht L.G.A. Janssen, EU bank resolution framework: A comparative study on the relation with national private law (diss. Leiden), 2019.

15. Dat was bijv. anders - op systeemniveau - voor zeer grote verzekeraars met omvangrijke financiële posities ten aanzien van andere significante financiële ondernemingen (zoals AIG Insurance), en op klantniveau kan dat anders zijn voor bepaalde verzekeraars met levens- en kapitaalverzekeringen, waarbij de verzekerden voor hun levensonderhoud afhankelijk waren van uitkering door de verzekeraar.

16. Wet van 28 november 2018 tot wijziging van de Wet op het financieel toezicht en enige andere wetten in verband met de herziening van het kader voor herstel en afwikkeling van verzekeraars (Wet herstel en afwikkeling van verzekeraars), Stb. 2018, 489.
In paragraaf 2 bespreken wij de Conservatrix-casus en de uitspraak van de Hoge Raad in dat kader. Paragraaf 3 gaat in op het nieuwe afwikkelingsinstrumentarium uit de Whav. In paragraaf 4 kijken we naar de belangrijkste aandachtspunten en verschillen tussen de overdrachtsregeling gebruikt in de Conservatrix-casus aan de ene kant en de afwikkelingsinstrumenten onder de Whav aan de andere. We sluiten in paragraaf 5 af met een conclusie.

\section{Conservatrix}

\subsection{DNB's interventieladder}

De relatief kleine levensverzekeraar ${ }^{17}$ Conservatrix bestaat al sinds 1872, en staat onder doorlopend toezicht van DNB. Haar 100\%-aandeelhouder was al enkele decennia de Luxemburgse holdingmaatschappij Conservatrix Groep. Conservatrix Groep is al lang in familiehanden. ${ }^{18}$ Het feitenverloop dat aan de basis staat van het Conservatrix-arrest geeft een illustratief en goed beeld van de zogenoemde interventieladder van DNB bij een financiële onderneming in financiële moeilijkheden, zoals wij dat in de praktijk regelmatig tegenkomen. ${ }^{19}$

\section{Informele maatregelen}

Rond 2009 bevindt Conservatrix zich in zwaar weer, waardoor zij onder verscherpt toezicht van DNB komt. In 2009 uit DNB eerst in gesprekken met Conservatrix haar zorgen over de bedrijfsvoering en dan met name de risicobeheersing. Kennelijk leidt dat niet tot een verbeterde situatie, waarna DNB vanaf begin 2012 haar zorgen uit over verdere door DNB geconstateerde tekortkomingen in de bedrijfsvoering en de financiële (solvabiliteits)positie van Conservatrix. DNB doet dat zowel mondeling als via brieven aan Conservatrix. De tekortkomingen bij Conservatrix betreffen volgens DNB onder andere de waardering van de hypotheekportefeuille, de waardering van de verplichtingen behorende bij het door

17. Blijkens haar jaarrekening 2018 had Conservatrix per 31 december 2018 een balanstotaal van $€ 574.366 .000$. Zie www.conservatrix.nl/ conservatrix/assets/File/Conservatrix\%20N_V_\%20-\%20Jaarrekening \%202018.pdf.

18. Wij zullen in dit artikel niet uitgebreid ingaan op de - overigens zeer interessante - geschiedenis van Conservatrix en haar voormalige eigenaars, de familie Henny. Zie daarvoor bijv. www.volkskrant.nl/ economie/dnb-pakt-bloedbroeders-verzekeringsbedrijf-af $\sim$ b67b7239/.

19. Het feitenrelaas baseren wij o.a. op de diverse uitspraken ten aanzien van Conservatrix, zoals o.m. Rb. Amsterdam 12 september 2016, ECLI:NL:RBAMS:2016:9823 (voorlopige voorziening om overdrachtsplan DNB te beletten); Hof Amsterdam 3 januari 2017, ECLI:NL:GHAMS:2017:272 (hoger beroep tegen vonnis Rb. Amsterdam 12 september 2016); Hof Amsterdam 4 april 2017, ECLI:NL:GHAMS:2017:1980 (enquêteprocedure OK); Rb. Amsterdam 15 mei 2017, ECLI:NL:RBAMS:2017:3309, Ondernemingsrecht 2017/99 m.nt. A.J.A.D. van den Hurk (de goedkeuring van het overdrachtsplan en het uitspreken van de overdrachtsregeling); HR 6 april 2018, ECLI:NL:HR:2018:538 (tussenbeschikking op vraag of cassatieberoep openstaat tegen uitspreken van overdrachtsregeling); HR 7 mei 2019, ECLI:NL:HR:2019:746, NJ 2019/389 m.nt. V.P.G. de Serière (cassatie op Rb. Amsterdam 15 mei 2017). Zie o.a. ook JOR 2019/189 m.nt. E.P.M. Joosen, incl. de uitvoerige conclusie van A-G Timmerman. Wij merken overigens op dat wij niet alle uitspraken in de diverse Conservatrix-procedures in dit artikel bespreken. 
Conservatrix aangeboden product Natuurlijk Garantieplan, en de beheersing van het renterisico.

\section{Aanwijzing en curator}

Ook dit informeel bijsturen door DNB mag kennelijk niet baten. DNB heeft ten aanzien van verzekeraars echter een aantal mogelijke formele herstelmaatregelen in haar pakket aan wettelijke bevoegdheden. Gelet op de aanhoudende financiële problemen van Conservatrix en zorgen van DNB over haar bedrijfsvoering besluit DNB op 1 april 2014 dan ook een aanwijzing te geven en een curator te benoemen ten aanzien van de directie van Conservatrix. ${ }^{20}$ DNB ontwaarde - in lijn met de wettelijke voorwaarden van het benoemen van een curator - bij Conservatrix onder meer tekenen van een ontwikkeling die het eigen vermogen en de solvabiliteit in gevaar konden brengen, en achtte onverwijld ingrijpen noodzakelijk.

DNB constateerde ook dat een kapitaaleis van Conservatrix ruimschoots werd onderschreden. Het destijds geldende theoretisch solvabiliteitscriterium (TSC) ${ }^{21}$ was $44 \%$, terwijl dat minimaal $100 \%$ diende te zijn. Om die reden verlangt DNB op 3 juli 2014 een herstelplan van Conservatrix. ${ }^{22}$

DNB vond het herstelplan kennelijk onvoldoende. Op 23 september 2014 stemde DNB niet in met dit herstelplan omdat dit, volgens haar, niet voorzag in een duurzame oplossing tot structureel herstel. Daarnaast gaf DNB een aanwijzing aan Conservatrix om (1) uiterlijk per 30 september 2014 een minimum aan solvabiliteit van $130 \%$ aan te houden, (2) met een concreet afbouwplan te komen voor een beheerste 'run off van haar verzekeringsportefeuille, en (3) uiterlijk eind 2014 aan te geven of er concreet zicht bestond op een overname van Conservatrix.

Zonder resultaat: bij brief van 13 januari 2015 deelt DNB aan Conservatrix mee dat zij heeft geconstateerd dat de drie eisen van de opgelegde gedragslijn in de aanwijzing van september 2014 niet zijn opgevolgd. Wel biedt Conservatrix vanaf 1 januari 2015 op instructie van DNB geen verzekeringsproducten meer aan en worden aflopende producten niet meer verlengd. Vervolgens laat DNB weten dat zij een zelfstandige afwikkeling onder de gegeven omstandigheden niet haalbaar acht, en dat - wat DNB betreft - alleen een overnametraject resteert.

Hiermee treedt een nieuwe fase aan, die van een M\&A-traject, dat aanvankelijk op 'vrijwillige' basis verloopt. Er melden zich vier min of meer concrete kopers voor Conservatrix en op 9 april 2015 wordt een 'letter of intent' opgesteld voor een overdracht van aandelen en/of de portefeuille van Conservatrix aan de Amerikaanse verzekeraar Eli Global LLC (hierna: Eli Global). In juni 2015 wordt vervolgens ook een Share

20. Op basis van respectievelijk art. 1:75 en 1:76 Wft.

21. Het TSC was een tijdelijke maatregel die in de aanloop naar en ter voorbereiding op Solvency II werd geïntroduceerd.

22. Op grond van art. 3:132 lid 1 (oud) Wft
Purchase Agreement (SPA) gesloten. Dit proces eindigt echter op 22 december 2015, nadat duidelijk is geworden dat de in de SPA opgenomen opschortende voorwaarden niet kunnen worden vervuld. Het vrijwillige overnametraject eindigt daarmee na een jaar zonder beoogd resultaat, en met Conservatrix gaat het - volgens DNB - nog niet veel beter.

\section{Afwikkelingsmaatregel en mogelijke intrekking vergunning} Dat brengt DNB ertoe een relatief nieuwe en tot dan toe nooit eerder gebruikte maatregel uit haar instrumentarium in te zetten: de overdrachtsregeling. Bij brief van 8 januari 2016 deelt zij Conservatrix formeel mee dat zij een overdrachtsplan voorbereidt (in de zin van art. 3:159c lid 1 (oud) Wft). In dat kader laat DNB Conservatrix en Conservatrix Groep weten dat zij verder exclusief onderhandelt over de overname met de meest gerede partij. DNB staat het Conservatrix en Conservatrix Groep enkel onder voorwaarden toe om parallel daaraan het 'vrijwillige overnametraject' te vervolgen. Een van die voorwaarden is dat dat ook onder exclusiviteit met dezelfde partij gebeurt, en dat Conservatrix de onderhandelingen met de resterende drie partijen actief staakt.

Omdat Conservatrix nog steeds niet aan haar kapitaaleisen voldoet, en zij op 1 september 2016 DNB informeert dat zij geen financieel kortetermijnplan indient, deelt DNB Conservatrix in oktober 2016 mee dat zij voornemens is haar vergunning in te trekken.

In het voorjaar van 2017 is het overdrachtsplan van DNB ten aanzien van Conservatrix gereed. Op grond van een aan DNB gerichte 'Confirmation Letter' van 17 maart 2017 dient Conservatrix Groep alle aandelen in Conservatrix over te dragen aan Trier Holding B.V. (hierna: Trier), een dochteronderneming van Eli Global. Op grond van de overdrachtsregeling dient Conservatrix Groep haar aandelen in Conservatrix voor $€ 1$ aan Trier over te dragen. Trier heeft in het overdrachtsplan ook toegezegd dat zij het eigen vermogen van Conservatrix substantieel zal aanvullen. Als gevolg daarvan zou Conservatrix weer aan haar kapitaaleisen voldoen. Op grond van de $\mathrm{Wft}$ treedt deze overdracht in werking na een ex-antegoedkeuring daarvan door de Rechtbank Amsterdam (hierna: de rechtbank).

\subsection{Deprocedure}

\section{Rechtbank}

In het kader van haar overdrachtsplan verzoekt DNB de rechtbank bij verzoekschrift van 22 maart 2017, voor zover hier relevant: ${ }^{23}$

1. het overdrachtsplan goed te keuren en de overdrachtsregeling uit te spreken ten aanzien van Conservatrix; en

2. te bepalen dat de aandelen in Conservatrix door de goedkeuring van het overdrachtsplan onbezwaard overgaan op

23. Rb. Amsterdam 15 mei 2017, ECLI:NL:RBAMS:2107:3309, JOR 2017/200 m.nt. R.J. Theissen, Ondernemingsrecht 2017/99 m.nt. A.J.A.D. van den Hurk. 
het tijdstip waarop de beschikking is gegeven (art. 3:159s lid $1 \mathrm{Wft}$ ).

Conservatrix zelf, als lijdend voorwerp van het overdrachtsplan, schikt zich naar het oordeel van de rechtbank. Haar aandeelhouder, de de facto onteigende Conservatrix Groep, voert echter verweer. $\mathrm{Zij}$ wordt door het overdrachtsplan immers verplicht afstand te doen van haar aandelen voor de luttele som van $€ 1$ en de toezegging van Trier dat zij het eigen vermogen van Conservatrix substantieel zal aanvullen, zodat aan de kapitaaleisen wordt voldaan.

De rechtbank overweegt ${ }^{24}$ dat zij voor de vraag of zij een overdrachtsplan kan goedkeuren en de overdrachtsregeling kan uitspreken, twee vragen dient te beantwoorden:

1. Blijkt summierlijk dat zich een situatie als bedoeld in art. 3:159c lid 1 (oud) Wft voordoet (art. 3:159ij lid 1 (oud) $\mathrm{Wft}$ )?

2. Is de in het overdrachtsplan genoemde prijs, gegeven de omstandigheden van het geval, niet een redelijke prijs (art. 3:159ij lid 2 (oud) Wft)?

Vraag 1 valt volgens de rechtbank uiteen in de twee subvragen die in art. 3:159c lid 1 (oud) Wft aan de orde komen:

a. Zijn er ten aanzien van Conservatrix tekenen van een gevaarlijke ontwikkeling met betrekking tot het eigen vermogen, de solvabiliteit of de technische voorzieningen?

b. Is redelijkerwijs te voorzien dat die ontwikkeling niet voldoende of niet tijdig ten goede zal keren?

Eerst moet de rechtbank echter een belangrijke voorvraag beantwoorden.

\section{- Recht op eigendom}

Voordat de rechtbank ingaat op de goedkeuring van het overdrachtsplan, bespreekt zij eerst de principiële vraag van de rechtsbescherming tegen de in het plan besloten 'onteigening' van de aandeelhouders van Conservatrix: Conservatrix Groep. ${ }^{25}$ De vraag is immers hoe het instrument van het overdrachtsplan is te rijmen met het mensenrecht op het ongestoorde genot van het eigendom in de zin van het Eerste protocol van het Europees Verdrag van de Rechten van de Mens (EVRM). In de Conservatrix-casus gaat het daarbij natuurlijk om het eigendom door Conservatrix Groep van de aandelen in Conservatrix. In dat kader haalt de rechtbank de uitgebreide parlementaire geschiedenis op dit punt bij de Interventiewet, waarmee het overdrachtsplan in de Wft werd neergelegd, aan. $^{26}$

De rechtbank overweegt ${ }^{27}$ - in het licht van de wetsgeschiedenis - dat er in dit kader drie vragen beantwoord moeten worden:

24. Rb. Amsterdam 15 mei 2017, ECLI:NL:RBAMS:2017:3309, r.o. 4.10. 25. Rb. Amsterdam 15 mei 2017, ECLI:NL:RBAMS:2107:3309, r.o. 4.11.

26. Kamerstukken II $2011 / 12,33059$, 3, p. 14-18.

27. Rb. Amsterdam 15 mei 2017, ECLI:NL:RBAMS:2107:3309, r.o. 4.11.1.
1. Is de maatregel in het algemeen belang?

2. Is de maatregel proportioneel?

3. Hebben aandeelhouders wier aandelen worden overgedragen voldoende rechtsmiddelen?

Kennelijk heeft Conservatrix Groep ten aanzien van deze vragen aangevoerd dat de rechtbank moest beoordelen (1) of het overdrachtsplan het algemeen belang diende, en (2) of het overdrachtsplan proportioneel was gelet op de beperkte impact voor het financiële stelsel als Conservatrix failliet zou gaan.

Ten aanzien van het eerste verweer, het ontbreken van het algemeen belang, overwoog de rechtbank dat het niet aan haar is om te beoordelen of de verzochte overdracht het algemeen belang dient. ${ }^{28}$ Aan de overdrachtsregeling liggen volgens de rechtbank weloverwogen keuzes van de wetgever ten grondslag. In die keuzes is onder andere het algemeen belang verdisconteerd, en mag en kan de rechtbank niet treden, zeker niet $\mathrm{nu}$ de wetgever een grote beoordelingsvrijheid (margin of appreciation) toekomt.

Ook het tweede verweer, het gebrek aan proportionaliteit, wees de rechtbank af. ${ }^{29}$ Daarbij merkte de rechtbank op dat de overdrachtsregeling alle Nederlandse verzekeraars betreft en geen onderscheid makt naar aard, omvang of andere kenmerken van de betrokken verzekeraar. Als DNB oordeelt dat er bij een verzekeraar tekenen van een gevaarlijke ontwikkeling zijn met betrekking tot het eigen vermogen, de solvabiliteit of de technische voorzieningen en redelijkerwijs is te voorzien dat die ontwikkeling niet voldoende of niet tijdig ten goede zal keren, kan zij nu eenmaal een overdrachtsplan voorbereiden (art. 3:159c lid 1 (oud) Wft). DNB komt daarbij volgens de rechtbank een ruime mate van beoordelings- en beleidsvrijheid toe.

Kortom, de rechtbank oordeelt dat het niet aan haar is om, in het geval van een concreet overdrachtsplan, te beoordelen of met die maatregel het algemeen belang is gediend of dat die maatregel proportioneel is. De rechtbank zelf komt in een concreet geval enkel een zeer beperkte toets toe van het overdrachtsplan en de noodzaak daartoe. ${ }^{30}$

\section{- Toetsing overdrachtsplan}

$\mathrm{Nu}$ de rechtbank tot de conclusie komt dat het instrument van het overdrachtsplan in algemene zin niet in strijd is met het recht op het ongestoorde genot van het eigendom, gaat zij over tot haar summiere beoordeling van elk van de drie goedkeuringsvoorwaarden uit art. 3:159ij (oud) Wft. Telkens beoordeelt de rechtbank of DNB voldoende redenen heeft aangevoerd op grond waarvan zij tot haar oordeel heeft kun-

28. Rb. Amsterdam 15 mei 2017, ECLI:NL:RBAMS:2107:3309, r.o. 4.11.2.

29. Rb. Amsterdam 15 mei 2017, ECLI:NL:RBAMS:2107:3309, r.o. 4.11.3.

30. Kennelijk is de rechtbank daarmee van mening dat aandeelhouders wier aandelen worden overgedragen in elk geval voldoende rechtsmiddelen hebben (deelvraag 3). 
nen komen. Wij bespreken de antwoorden van de rechtbank hieronder beknopt.

1.a Zijn er ten aanzien van Conservatrix tekenen van een gevaarlijke ontwikkeling met betrekking tot het eigen vermogen, de solvabiliteit of de technische voorzieningen? Hier gaat de rechtbank de door de wetgever in de wetsgeschiedenis gegeven elementen af: (a) het betreft de solvabiliteit, (b) met betrekking waartoe er tekenen moeten zijn (c) van een ontwikkeling (d) die gevaarlijk is. In het licht van de door DNB gegeven toelichting op die punten is de rechtbank van oordeel dat summierlijk blijkt van tekenen van een gevaarlijke ontwikkeling ten aanzien van de solvabiliteit van Conservatrix, althans dat DNB voldoende redenen heeft aangevoerd op grond waarvan zij tot dat oordeel heeft kunnen komen. ${ }^{31}$

1.b Is redelijkerwijs te voorzien dat die ontwikkeling niet voldoende of niet tijdig ten goede zal keren?

De rechtbank oordeelt dat summierlijk blijkt dat de gevaarlijke ontwikkeling ten aanzien van de solvabiliteit van Conservatrix niet voldoende of niet tijdig ten goede kan worden gekeerd, althans dat DNB voldoende redenen heeft aangevoerd op grond waarvan zij tot dat oordeel heeft kunnen komen. Dat oordeel licht de rechtbank toe aan de hand van vijf omstandigheden die ertoe leiden dat niet voldoende aannemelijk kan worden gemaakt dat de geconstateerde gevaarlijke ontwikkeling ten aanzien van de solvabiliteit wel voldoende of tijdig ten goede kan worden gekeerd. ${ }^{32}$

2. Is de in het overdrachtsplan genoemde prijs, gegeven de omstandigheden van het geval, niet een redelijke prijs?

De rechtbank somt de haar ter beschikking staande informatie over de vaststelling van de prijs die Trier betaalt voor de aandelen in het overdrachtsplan op. Vervolgens geeft zij aan dat zij geen grond heeft om te oordelen dat de prijs, gegeven de omstandigheden van het geval, niet een redelijke prijs is. Opnieuw heeft de rechtbank volgens zichzelf een beperkte rol. Het lijkt de rechtbank niet aan haar om een verder oordeel over de daadwerkelijke prijs te vellen. ${ }^{33}$

$\mathrm{Nu}$ vraag 1 positief is beantwoord en vraag 2 negatief, keurt de rechtbank het overdrachtsplan goed en spreekt zij de overdrachtsregeling uit ten aanzien van Conservatrix. Conservatrix Groep gaat in cassatie.

31. Rb. Amsterdam 15 mei 2017, ECLI:NL:RBAMS:2107:3309, r.o. 4.13.3.

32. Rb. Amsterdam 15 mei 2017, ECLI:NL:RBAMS:2107:3309, r.o. 4.14.

33. Rb. Amsterdam 15 mei 2017, ECLI:NL:RBAMS:2107:3309, r.o. 4.15. De rechtbank geeft daarbij aan dat het op grond van art. 3:159ab lid 1 (oud) Wft aan de aandeelhouder vrijstaat om de Ondernemingskamer van het gerechtshof te Amsterdam te verzoeken een aanvullende schadevergoeding vast te stellen, als de aandeelhouder van mening is dat de door de overnemer te betalen prijs geen volledige vergoeding vormt voor de schade die hij rechtstreeks en noodzakelijk door het verlies van zijn aandeel lijdt. Ook wijst de rechtbank op het gegeven dat art. 3:159ij lid 2 (oud) Wft als een 'tenzij-clausule' is geformuleerd; er dient goedkeuring te worden verleend, 'tenzij de prijs (...) niet een redelijke prijs is'.

\section{Kritiek en conclusie A-G Timmerman}

Op de uitspraak van de rechtbank volgden de nodige op- en aanmerkingen in de literatuur. ${ }^{34} \mathrm{Zo}_{\mathrm{o}}$ is een belangrijke aanmerking van Theissen en Van den Hurk op de rechtbankuitspraak kort gezegd dat de rechtbank ook de noodzaak van het overdrachtsplan in de concrete Conservatrix-situatie aan het algemeen belang had moeten toetsen, om zo inbreuk op het eigendomsrecht van Conservatrix Groep te rechtvaardigen. $\mathrm{Zij}$ stellen daarbij de vraag of - gelet op onder andere de beperkte omvang van Conservatrix en de geringe impact op polishouders - het overdrachtsplan wel in het algemeen belang was. Zoals hierboven al uiteengezet, toetste de rechtbank echter enkel de totstandkoming van de wettelijke regeling van het overdrachtsplan aan het algemeen belang. Zij kwam daarbij tot de conclusie dat de wetgever in dat kader een weloverwogen besluit had genomen en de wetgever wat dat betreft een grote beoordelingsvrijheid (margin of appreciation) toekomt. Om die reden vond de rechtbank dat het niet aan haar was om dat in een concreet geval te toetsen.

Naast de afwezigheid van de toetsing van het overdrachtsplan aan het algemeen belang, heeft Conservatrix Groep nog een aanzienlijk aantal andere cassatiemiddelen. Deze worden in de gedetailleerde conclusie van A-G Timmerman behandeld. ${ }^{35}$ Timmerman acht de klachten van Conservatrix Groep een voor een ongegrond. Over de toetsing van het concrete overdrachtsplan aan het algemeen belang merkt Timmerman op dat de algemeen-belangtoets voor het concrete geval besloten ligt in de summiere toetsingsmaatstaf die de wetgever heeft meegegeven in art. 3:159ij lid 1 jo. art. 3:159c lid 1 (oud) Wft.

\section{Het arrest van de Hoge Raad}

De Hoge Raad is relatief beknopt in zijn oordeel. ${ }^{36}$ De Hoge Raad gaat alleen in op onderdeel 2 van het middel van Conservatrix Groep. Daarin klaagt Conservatrix Groep onder meer dat de rechtbank ten onrechte het verzoek van DNB heeft beoordeeld op een terughoudende wijze, die neerkomt op een marginale toetsing. Volgens Conservatrix Groep had de rechtbank ten volle moeten onderzoeken of de door DNB verzochte overdracht noodzakelijk was.

34. Zie M.L.H. Reumers, Over verzekeraars in financiële moeilijkheden, TvCu 2017, afl. 4, p. 135-144, R.J. Theissen, annotatie bij Rb. Amsterdam 15 mei 2017, ECLI:NL:RBAMS:2017:3309, JOR 2017/200 en A.J.A.D. van den Hurk, annotatie bij Rb. Amsterdam 15 mei 2017, ECLI:NL:RBAMS:2017:3309, Ondernemingsrecht 2017/99, p. 560-563.

35. Voor een lezenswaardige, grondige en volledige analyse van de Conservatrix-zaak in het bijzonder, en het financieel toezichtrecht ten aanzien van verzekeraars in het algemeen (zowel onder de oude als onder de nieuwe afwikkelingsregels), zij verwezen naar deze conclusie. Zie in vergelijkbare zin E.P.M. Joosen, annotatie bij HR 17 mei 2019, ECLI:NL:HR: 2019:746, JOR 2019/9, p. 2441-2443, randnr. 8: 'De Hoge Raad volgt hierbij de (magistrale) conclusie van A-G Timmerman, waarvan gezegd moet worden dat het een van de mooiste en meest diepgravende analyses is die ik in mijn hele carrière als jurist heb mogen lezen.'

36. HR 17 mei 2019, ECLI:NL:HR:2019:746, NJ 2019/389 m.nt. V.P.G. de Serière. Zie o.a. ook JOR 2019/189 m.nt. E.P.M. Joosen, incl. de uitvoerige conclusie van A-G Timmerman. 
De Hoge Raad haalt een hele reeks passages uit de wetsgeschiedenis aan die gaan over de toetsing van een overdrachtsplan door de rechtbank. Uit al deze passages, individueel en in samenhang bezien, trekt de Hoge Raad de conclusie dat 'met de uiteenlopende formuleringen steeds hetzelfde is bedoeld, te weten dat de rechter het verzoek terughoudend beoordeelt'. De Hoge Raad geeft daarbij aan dat de rechtbank oordeelt dat DNB bij de toepassing van het overdrachtsplan een ruime mate van beoordelings- en beleidsvrijheid toekomt, en dat de rechtbank eveneens van mening is dat de rechterlijke toetsing of zich een situatie als bedoeld in die bepaling voordoet, een beperkte is.

Vervolgens citeert de Hoge Raad de overwegingen op grond waarvan de rechtbank tot de conclusie komt dat de eerste vraag - of summierlijk blijkt dat zich een situatie als bedoeld in art. 3:159c lid 1 (oud) Wft heeft voorgedaan - positief moet worden beantwoord. De Hoge Raad is van oordeel dat de rechtbank hiermee op de juiste wijze tot haar oordeel is gekomen:

'Dat de rechtbank in rov. 4.13 .3 en 4.14 .4 overweegt dat DNB voldoende redenen heeft aangevoerd op grond waarvan DNB tot het daar onderzochte oordeel heeft kunnen komen, betekent niet dat de rechtbank bij haar beoordeling te terughoudend is geweest. In de eerste plaats blijkt uit de parlementaire geschiedenis, zoals hiervoor in 3.4.2-3.4.6 weergegeven, dat de wetgever met het vervangen in art. 3:159ij lid 1 (oud) Wft van het criterium "in redelijkheid niet heeft kunnen komen tot het oordeel" door "summierlijk blijken" niet heeft beoogd de rechter het verzoek anders dan terughoudend te laten beoordelen. In de tweede plaats heeft de rechtbank in de bedoelde overwegingen ook, en wel in de eerste plaats, onderzocht of aan het criterium "summierlijk blijken" was voldaan, hetgeen volgens de rechtbank het geval was. In de derde plaats blijkt uit de motivering van de beslissingen van de rechtbank dat zij de oordelen van DNB en de daartegen door Conservatrix Groep aangevoerde argumenten inhoudelijk heeft onderzocht en daarbij niet terughoudender is geweest dan de wettelijke regeling voorschrijft. De klacht faalt daarom. ${ }^{37}$

Kortom, de Hoge Raad leunt sterk op de parlementaire geschiedenis en oordeelt dat de wetgever heeft beoogd dat de rechter het verzoek tot het goedkeuren van het overdrachtsplan terughoudend dient te beoordelen. De rechtbank heeft dat terughoudende onderzoek naar het overdrachtsplan van DNB vervolgens op de juiste manier verricht. Daarmee bevestigt de Hoge Raad ook het oordeel van de rechtbank dat DNB een ruime beleids- en beoordelingsvrijheid heeft bij de toepassing van de toetsingsmaatstaf van art. 3:159c (oud) Wft.
De Hoge Raad verwerpt het beroep van Conservatrix Groep, en komt niet meer toe aan een aantal interessante punten. Daarbij valt bijvoorbeeld te denken aan de toetsing van de 'onteigening' aan het algemeen belang, de vraag of DNB de toepasselijke solvabiliteitseisen niet te streng uitlegde, en de wijze waarop DNB de waarde van de aandelen bepaalde.

\section{Wet herstel en afwikkeling verzekeraars}

\subsection{Inleiding}

Zoals hierboven in paragraaf 1 aangegeven, is op 1 januari 2019 een overkoepelend herstel- en afwikkelingskader voor verzekeraars geïntroduceerd: de Whav. ${ }^{38}$ De verschillende oude interventiemaatregelen, waaronder dus de overdrachtsregeling uit de Conservatrix-zaak, sloten bijvoorbeeld niet goed op elkaar aan en waren deels overlappend. ${ }^{39}$ Daarbij merkte de minister ook op dat het steeds slechter gaat met de verzekeringssector, waardoor er een reële kans bestaat dat verzekeraars in de problemen kunnen komen. ${ }^{40}$

Daarbij was de wetgever op zoek naar een kader dat voorzag in een alomvattende procedure, waarbinnen DNB voor de maatregel kan kiezen die in een concreet geval het meest passend is. Hierbij baseerde de wetgever zich op de BRRD. De Whav trad per 1 januari 2019 via aanpassingen aan de Wft en de Fw in werking, en verving de overdrachtsregeling.

De Whav is, kort gezegd, van toepassing op alle verzekeraars waarop door DNB toezicht wordt uitgeoefend en bepaalde andere ondernemingen binnen een groep waarvan een dergelijke verzekeraar deel uitmaakt.

Net zoals de BRRD omvat de Whav diverse fases: (1) een voorbereidingsfase en (2) een afwikkelingsfase. In de voorbereidingsfase worden aan verzekeraars en DNB verplichtingen opgelegd in het kader van herstel- en afwikkelingsplanning, terwijl in de afwikkelingsfase aan DNB bevoegdheden worden toegekend die herstel en afwikkeling van verzekeraars moeten bewerkstelligen. Voor beide fases is een aantal nieuwe verplichtingen en maatregelen geïntroduceerd.

\subsection{De voorbereidingsfase}

In deze fase verkeert een verzekeraar nog niet in financiële problemen, maar dient een aantal plannen te worden opgesteld om, indien nodig, direct maatregelen te kunnen nemen, al dan niet als DNB dat van de verzekeraar eist.

38. Zie voor een nuttig overzicht o.m. B.W.G. van der Velden \& V.P.G. de Serière, Het wetsvoorstel herstel en afwikkeling van verzekeraars. Een ambitieus, geheel vernieuwd Nederlands regime voor het herstel en de afwikkeling van verzekeraars in nood, FR 2018, afl. 1/2, p. 47-61 en A.J.A.D. van den Hurk, Het wetsvoorstel herstel en afwikkeling van verzekeraars, Ondernemingsrecht 2018/57, p. 333-341. Zie ook A.J.A.D. van den Hurk, Het consultatiedocument voor de Wet herstel en afwikkeling verzekeraars, Ondernemingsrecht 2016/97, p. 480-484.

39. Kamerstukken II $2017 / 18,34842,3$, p. 6.

40. Kamerstukken II 2017/18, 34842, 3, p. 1.

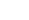


De Whav heeft met betrekking tot de voorbereidingsfase de volgende nieuwe maatregelen geïntroduceerd: ${ }^{41}$

- Het voorbereidend crisisplan: de verzekeraar of holding is verplicht om in financieel gezonde tijden een voorbereidend crisisplan op te stellen. In dit plan wordt uiteengezet welke maatregelen hij kan nemen op het moment dat zijn financiële positie aanzienlijk verslechtert. Dit plan moet worden goedgekeurd door DNB. De beoordeling van het voorbereidend crisisplan door DNB geldt als besluit waartegen bestuursrechtelijk bezwaar en beroep openstaat. ${ }^{42}$

- Het afwikkelingsplan: DNB is verplicht een afwikkelingsplan op te stellen voor iedere specifieke verzekeraar of verzekeringsgroep. Hierin zet DNB uiteen welke afwikkelingsinstrumenten en -bevoegdheden zij heeft. Op het moment dat DNB wezenlijke belemmeringen voor de afwikkelbaarheid van een verzekeraar of groep constateert, is zij bevoegd de verzekeraar of groepsentiteit te verplichten maatregelen te nemen om deze belemmeringen weg te nemen.

\subsection{De afwikkelingsfase}

Mochten eventuele pogingen tot herstel van de verzekeraar niet baten, dan heeft DNB de bevoegdheid om te besluiten tot afwikkeling van de verzekeraar en treedt de afwikkelingsfase aan. Uitgangspunt is echter dat voordat DNB het afwikkelingsbesluit kan nemen, zij in beginsel eerst de normale interventieladder binnen het doorlopende toezicht moet doorlopen. Onderdeel daarvan zijn het herstelplan en het financieel kortetermijnplan.

Als de normale interventieladder geen uitkomst heeft geboden, mag DNB pas overgaan tot afwikkeling als aan elk van de volgende drie voorwaarden is voldaan:

1. De verzekeraar faalt of zal waarschijnlijk falen.

2. Er is geen redelijk vooruitzicht dat alternatieve maatregelen binnen een afzienbare tijd de situatie ten goede zullen keren.

3. De afwikkeling van de verzekeraar is in het algemeen belang. ${ }^{43}$

De Whav werkt deze drie voorwaarden vervolgens verder uit.

\section{Ad 1. Falen of waarschijnlijk falen}

Interessant zijn de bepalingen waarin wordt geregeld wanneer een verzekeraar geacht wordt te falen of waarschijnlijk te falen. ${ }^{44}$ Hiervan is sprake als:

a. de verzekeraar op een zodanige wijze inbreuk maakt op de wettelijke eisen, de vergunningsvereisten of de aan de vergunning verbonden voorwaarden, of er objectieve aanwijzingen bestaan voor de veronderstelling dat de ver-

41. Zie art. 3:288 lid 1, 3a:81 en 3a:83 Wft.

42. In haar Good practice. Voorbereidend crisisplan van 25 juli 2019 heeft DNB verzekeraars van guidance voorzien over haar verwachtingen met betrekking tot het voorbereidend crisisplan. Zie www.toezicht.dnb.nl/ binaries/50-237775.pdf.

43. Art. 3a:85 lid $1 \mathrm{Wft}$.

44. Art. 3a:85 lid $2 \mathrm{Wft}$. zekeraar in de nabije toekomst op een zodanige wijze daarop inbreuk zal maken, dat intrekking van de vergunning gerechtvaardigd is;

b. de waarde van de activa van de verzekeraar geringer is dan de waarde van de passiva, of er objectieve aanwijzingen zijn dat de activa van de verzekeraar in de nabije toekomst geringer zullen zijn dan zijn passiva;

c. de verzekeraar niet in staat is, of er objectieve aanwijzingen zijn voor de vaststelling dat de verzekeraar in de nabije toekomst niet in staat zal zijn, zijn schulden of andere passiva te betalen wanneer deze opeisbaar worden; of

d. voor het voortbestaan van de verzekeraar van overheidswege te verstrekken financiële steun noodzakelijk is.

Als een van deze criteria zich voordoet, is aan de eerste voorwaarde (falen of waarschijnlijk falen) voldaan. Het eerste criterium lijkt het belangrijkste criterium te zijn voor de vraag of een verzekeraar geacht wordt te falen of dat waarschijnlijk zal doen. De Wft vereist dat de vergunning van een verzekeraar wordt ingetrokken indien het kortetermijnplan dat moet worden opgesteld als het minimumkapitaalvereiste wordt onderschreden, niet tot het gewenste resultaat heeft geleid. Als dat in voorkomend geval aan de orde is, is daarmee dus automatisch voldaan aan het eerste criterium.

\section{Ad 2. Geen vooruitzicht dat alternatieve maatregelen belpen}

Bij de 'alternatieve maatregelen' uit de tweede voorwaarde valt te denken aan een kapitaalstorting door de aandeelhouder of een derde. Overigens meent de wetgever dat als het kortetermijnplan dat moet worden opgesteld bij onderschrijding van het minimumkapitaalvereiste niet tot een bevredigend resultaat heeft geleid, DNB mag aannemen dat aan deze tweede voorwaarde is voldaan.

\section{Ad 3. Algemeen belang}

Als aan de eerste twee voorwaarden is voldaan, wordt het interessant. Volgens de wetsgeschiedenis ${ }^{45}$ moet DNB nu een afweging gaan maken. DNB moet dan kiezen tussen enerzijds faillissement en liquidatie van de verzekeraar conform de Fw en anderzijds afwikkeling van de verzekeraar op grond van de Whav. De wetgever gaat er daarbij van uit dat faillissement de default is: in geval van een falende verzekeraar failleert deze, tenzij er sprake is van een algemeen belang dat afwikkeling rechtvaardigt. ${ }^{46}$

De keuze die DNB moet maken, is dus afhankelijk van de derde voorwaarde, namelijk de vraag of afwikkeling in het algemeen belang is. Blijkens de wetsgeschiedenis heeft DNB bij deze beoordeling 'enige mate van beoordelingsvrijheid'. ${ }^{47}$ Getoetst wordt dan of het ingrijpen door middel van afwikkelingsinstrumenten wel noodzakelijk en proportioneel is, gelet

45. Kamerstukken II 2017/18, 34842, 3, p. 18

46. Kamerstukken II 2017/18, 34842, 3, p. 73.

47. Kamerstukken II 2017/18, 34842, 3, p. 73. 
op de doelstellingen van afwikkeling, en of een normale faillissementsprocedure niet tot dezelfde resultaten zou leiden.

Er is volgens de Whav sprake van afwikkeling in het algemeen belang als een van de doelen genoemd in art. 3a:84 Wft door toepassing van een afwikkelinstrument tot een beter resultaat leidt dan een faillissement. Deze doelen zijn:

a. bescherming van de belangen van polishouders;

b. het voorkomen van grote maatschappelijke gevolgen;

c. het voorkomen van significante nadelige gevolgen voor de financiële markten of de economie; of

d. het voorkomen van de inzet van door de overheid te verstrekken financiële middelen.

Daarbij geldt dat het doel van bescherming van polishouders (doelstelling a) in samenhang dient te worden bezien met een van de drie andere doelen. Bij de afweging of afwikkeling in het algemeen belang is of dat faillissement afdoende is, moet dus breder worden gekeken dan enkel naar het belang van (een in theorie zeer kleine groep) polishouders. Bij de beoordeling of sprake zal kunnen zijn van het voorkomen van grote maatschappelijke gevolgen of significante nadelige gevolgen voor de financiële markten of de economie, zullen de schaal van de activiteiten van de verzekeraar (aantal polishouders) en het type verzekering (een inkomens- of kapitaalverzekering of een simpelere schadeverzekering) relevante factoren zijn. In de wetsgeschiedenis wordt opgemerkt dat in ieder geval kan worden gesteld dat afwikkeling voor (middel)grote verzekeraars ( $>1$ miljoen polishouders of $>€ 1$ miljard aan technische voorzieningen) in de rede ligt. ${ }^{48}$ Onder de Whav is afwikkeling in plaats van faillissement dus bepaald geen gegeven.

Terwijl we net zagen dat DNB bij de beoordeling of afwikkeling in een concreet geval in het algemeen belang is een zekere mate van beoordelingsvrijheid toekomt, heeft het besluit om tot afwikkeling over te gaan een imperatief karakter. Dat betekent dat als aan de drie voorwaarden (falen of waarschijnlijk zullen falen, geen alternatieve oplossing voorhanden en in het algemeen belang) wordt voldaan, DNB tot afwikkeling moet overgaan.

Voor wat betreft rechtsbescherming tegen een afwikkelingsbesluit van DNB staat uitsluitend een rechtsgang open in beroep (zonder bezwaar) naar het College van Beroep voor het bedrijfsleven $(\mathrm{CBb})$ in eerste en enige aanleg met verkorte termijnen. ${ }^{49}$ De verkorte termijn voor het instellen van het beroep is tien dagen, en het $\mathrm{CBb}$ moet uiterlijk veertien dagen na het instellen van beroep uitspraak doen. Tegen de uitspraak van het $\mathrm{CBb}$ staan geen rechtsmiddelen meer open.

Als DNB in een concrete situatie van oordeel is dat een faillissement de voorkeur verdient boven afwikkeling, biedt de Whav hiervoor aan een (zich) benadeeld(e) (voelende) polishouder geen specifieke rechtsbeschermingsmogelijkheden.

48. Kamerstukken II 2017/18, 34842, 3, p. 17.

49. Art. 3a:135 Wft. Zie ook Kamerstukken II 2017/18, 34842, 3, p. 30-31.
Een polishouder kan bijvoorbeeld menen dat hij in een betere positie had verkeerd wanneer niet het faillissement zou zijn aangevraagd, maar wanneer DNB zou hebben besloten tot afwikkeling. In een dergelijk geval zal deze polishouder zijn heil moeten zoeken in het reguliere faillissementsrecht, in het bijzonder art. $10 \mathrm{Fw}$, en verzet moeten instellen tegen de faillietverklaring. In deze verzetsprocedure zal hij vervolgens moeten aantonen dat afgewikkeld had moeten worden, omdat is voldaan aan het vereiste dat de afwikkeling in het algemeen belang is. Geen lichte taak.

\subsection{No creditor worse off}

$\mathrm{Al}$ san de drie voorwaarden is voldaan, kan DNB in beginsel overgaan tot afwikkeling. Wel dient DNB zich daarbij te houden aan het no creditor worse off (NCWO)-beginsel. Dit houdt in dat een schuldeiser of aandeelhouder van een verzekeraar in de afwikkeling niet slechter af mag zijn dan wanneer de verzekeraar in een regulier faillissement zou zijn geliquideerd. Concreet betekent dit dat de aandeelhouders of de schuldeisers van de verzekeraar waarvan vorderingen zijn afgeschreven of omgezet als gevolg van een afwikkelingsmaatregel van DNB geen grotere verliezen mogen lijden dan zij zouden hebben geleden als de verzekeraar onmiddellijk voorafgaand aan dat afwikkelingsbesluit zou zijn geliquideerd door middel van een faillissement. ${ }^{50}$

Met het oog hierop is een complex stelsel van onafhankelijke waardering ex ante, doorlopend en ex post in het leven geroepen. ${ }^{51}$ De complexiteit van dit stelsel is er onder meer in gelegen dat het afwikkelingsscenario wordt vergeleken met een puur hypothetische situatie: een fictief, zich immers niet voordoend, faillissement. Daarbij is de kwantitatieve waardering van voor de verzekeringssector kenmerkende toekomstige, in een onzekere gebeurtenis schuilende, vorderingen ook zeer ingewikkeld. Als het NCWO-beginsel wordt geschonden - dat wil zeggen: als uit de ex-postwaardering blijkt dat een houder van eigendomsinstrumenten of een schuldeiser grotere verliezen heeft geleden dan hij zou hebben geleden in faillissement - , krijgen de crediteuren het verschil terug ten laste van een speciaal hiervoor in het leven geroepen expostfinancieringsregeling. ${ }^{52}$ Ten behoeve van deze financieringsregeling zullen bijdragen worden geheven van Nederlandse Solvency II-verzekeraars. Deze bijdragen hebben een ex-postkarakter; anders dan voor banken zal dus geen fonds worden gevormd.

De Whav voorziet in reguliere bestuursrechtelijke rechtsbescherming ter zake van de vraag in hoeverre een recht bestaat op schadeloosstelling voor schending van het NCWO-beginsel. Deze vangt aan met een besluit van DNB op grond van art. 3a:91 lid $4 \mathrm{Wft}$ of een weigering van $\mathrm{DNB}$ om een dergelijk besluit te nemen. Dit besluit hangt samen met de uitkomst van de ex-postwaardering, waaruit moet blijken in hoeverre

50. Kamerstukken II 2017/18, 34842, 3, p. 4 en art. 3A:88 Wft.

51. Art. 3A:89 t/m 3A:91 Wft.

52. Art. 3A:138 Wft en Kamerstukken II 2017/18, 34842, 3, p. 32-33. 
aan het NCWO-beginsel is voldaan. Voor deze rechtsgang geldt dus niet de uitsluiting van bezwaar noch de versnelde behandeling in eerste en enige aanleg bij het $\mathrm{CBb}$, zoals dat wel het geval is ter zake van de vraag naar de rechtmatigheid van het besluit tot afwikkeling van een verzekeraar.

\subsection{Het afwikkelinstrumentarium}

DNB heeft onder de Whav vier afwikkelingsinstrumenten tot haar beschikking. Daarbij kan onderscheid worden gemaakt tussen bail-in enerzijds en overdrachtsinstrumenten anderzijds: ${ }^{53}$

\section{Bail-in}

Met het gebruik van het instrument van de bail-in kan DNB vorderingen van kapitaalverschaffers of andere schuldeisers (waaronder polishouders) van de verzekeraar afschrijven of omzetten in eigendomsinstrumenten. In principe valt de hele passiefzijde van de balans van de verzekeraar onder het bereik van bail-in. Voor toepassing van de bail-in wordt de omgekeerde rangorde gehanteerd waarop vorderingen in faillissement voor vergoeding in aanmerking zouden komen (dus: aandeelhouders worden als eersten aan de toepassing van bail-in onderworpen).

2. Overgang van onderneming

Het instrument van de overgang van onderneming is evenals de overbruggingsinstelling en de afsplitsing van activa en passiva een overdrachtsinstrument. Dit instrument biedt DNB de mogelijkheid eigendomsinstrumenten of activa en passiva over te dragen aan een private partij. Hierbij zijn twee soorten overgangen mogelijk. Bij de eerste kan DNB de eigendomsinstrumenten die zijn uitgegeven door de entiteit zelf overdragen. Zo ontstaat er een nieuwe eigenaar/aandeelhouder en blijven de activa onderdeel van de verzekeraar. Bij de tweede kan DNB de activa of passiva overdragen of een deel daarvan. Hierbij kan worden gedacht aan een portefeuilleoverdracht van de falende verzekeraar aan een derde. De overnemende partij betaalt daarvoor een prijs. De instemming van de verzekeraar is niet nodig, enkel van de overnemer. ${ }^{54}$

3. Overbruggingsinstelling

Bij gebruik van een 'overbruggingsinstelling' worden eigendomsinstrumenten of activa en passiva tijdelijk overgedragen aan een overbruggingsinstelling. Deze maatregel kan worden genomen op het moment dat er niet direct een private partij kan worden gevonden.

4. Afsplitsing van activa en passiva

Dit instrument ziet enkel op de activa en passiva en niet op eigendomsinstrumenten. DNB kan hierbij activa en passiva splitsen en tijdelijk onderbrengen bij een entiteit voor activa- en passivabeheer, om zo op een later tijdstip meer opbrengst te generen dan het bij verkoop nu zou doen. ${ }^{55}$ Dit instrument mag alleen in combinatie met andere afwikkelingsinstrumenten worden toegepast ten-

53. Afdeling 3A.2.4 Wft. Wij bespreken de instrumenten zeer beknopt.

54. Kamerstukken II 2017/18, 34842,3 , p. 25.

55. Van der Velden \& De Serière 2018, p. 49. einde een onterecht concurrentievoordeel voor de falende entiteit te vermijden.

\section{Belangrijke aandachtspunten}

\subsection{Inleiding}

Hierboven hebben we uitgebreid gekeken naar het overdrachtsplan en de Conservatrix-uitspraak onder het oude recht aan de ene kant en naar de daarvoor in de plaats gekomen afwikkelingsmaatregelen onder de nieuwe Whav aan de andere kant. Naar onze mening is uit deze vergelijking een aantal interessante, en voor de praktijk relevante, aandachtspunten en verschillen te destilleren ten aanzien van de mogelijkheid van DNB om onder het huidige recht tot afwikkeling van een verzekeraar over te gaan. Wij concentreren ons hierbij op (1) de materiële toets die DNB moet doen, (2) de veranderde rechtsgang en (3) het NCWO-beginsel.

\subsection{Materiële toets DNB}

Op de eerste plaats verwachten wij dat de materiële toets die DNB in een concreet geval onder de Whav zal doen voorafgaand aan een besluit tot het nemen van een afwikkelingsmaatregel uitgebreider en gedetailleerder zal zijn dan bij het overdrachtsplan onder het oude recht het geval was.

Onder het oude recht, zoals tot uiting kwam in de Conservatrix-uitspraak, volstond het dat DNB in haar overdrachtsplan voldoende redenen aanvoerde dat sprake was van een gevaarlijke ontwikkeling met betrekking tot het eigen vermogen, de solvabiliteit of de technische voorzieningen, en dat die ontwikkeling redelijkerwijs niet voldoende of tijdig ten goede kon worden gekeerd.

A-G Timmerman en De Serière lijken - als hierboven aangegeven - van mening dat de oude regelgeving met dit criterium op zichzelf wel een algemeen-belangtoets voor een concreet overdrachtsplan bevatte, maar dat die impliciet verwerkt was in de maatstaf van art. 3:159c en 3:159ij (oud) Wft. ${ }^{56} \mathrm{Wij}$ vragen ons af of deze oude maatstaf wel een impliciete concrete algemeen-belangtoets omvatte. De wetsgeschiedenis bij de overdrachtsregeling zegt daar in elk geval niets over, terwijl deze wel expliciet een concrete algemeen-belangtoets voor onteigening door de minister van Financiën uit hoofde van art. 6:2 Wft beschreef. Ook inhoudelijk leek een toets aan het algemeen belang te ontbreken. Een gevaarlijke ontwikkeling met betrekking tot het eigen vermogen, de solvabiliteit of de technische voorzieningen van de verzekeraar is naar haar aard instellingsspecifiek. Deze toets richt zich daarom intrinsiek al niet tot het algemeen belang (het publiek, de stabiliteit van het financiële stelsel). Dit is alleen anders als aangenomen zou worden dat het faillissement van een verzekeraar, hoe onbete-

56. Concl. A-G Timmerman, ECLI:NL:PHR:2019:184, bij HR 17 mei 2019, NJ 2019/389 m.nt. V.P.G. de Serière, randnr. 3.66 en V.P.G. de Serière, annotatie bij HR 17 mei 2019, ECLI:NL:HR:2019:746, NJ 2019/389, randnr. 8 . 


\section{Maandblad}

kenend ook, altijd in het algemeen belang voorkomen zou moeten worden. Wij zouden menen dat dat niet zo is bedoeld.

Wat daar ook van zij, onder het huidige recht gaat de Whav - naast een instellingsspecifieke toets - wel uit van een expliciete algemeen-belangtoets. Daarbij is ook duidelijk dat een afwikkelingsmaatregel een ultimum remedium dient te zijn.

De instellingsspecifieke toets of de verzekeraar faalt of waarschijnlijk zal falen, waarbij de wet specifieke criteria geeft, lijkt sterk op de toets van de overdrachtsregeling. Dit erkent ook de wetgever: ${ }^{57}$

'Alle criteria hebben deels een voorspellend, toekomstig karakter. Er wordt immers gewezen op “objectieve aanwijzingen bestaan ter ondersteuning van de veronderstelling dat in de nabije toekomst" bijvoorbeeld de activa geringer zullen zijn dan de passiva. Er wordt aldus verlangd dat, alhoewel in dit voorbeeld de activa nog niet geringer zijn dan de passiva, in zekere zin voorzienbaar is dat dit in de nabije toekomst wel het geval zal zijn. Hierover behoeft echter geen absolute zekerheid te bestaan, en dat is ook niet mogelijk. Een dergelijke "garantie" kan immers bezwaarlijk worden vereist nu de toekomst per definitie ongewis is. Voldoende is dat er objectieve aanwijzingen zijn die een dergelijke vaststelling ondersteunen. Dit criterium komt in sterke mate overeen met het thans geldende criterium voor toepassing van de overdrachtsregeling, namelijk dat er tekenen zijn van een gevaarlijke ontwikkeling met betrekking tot de solvabiliteit of de technische voorzieningen van een verzekeraar.'

$\mathrm{Na}$ het slagen van de instellingsspecifieke 'faal'-toets en de conclusie dat redelijkerwijs geen alternatieve maatregelen voorhanden zijn, dient DNB in een concreet geval vervolgens steeds de vraag te beantwoorden of een afwikkeling in het algemeen belang is. Hierbij is van belang dat voor de beoordeling of een afwikkelingsbesluit in het algemeen belang is, DNB volgens de wetgever 'enige mate van beoordelingsvrijheid' heeft. ${ }^{58}$ Als dat niet het geval is, dient de normale faillissementsprocedure te worden gestart. Verzekeraars moeten immers gewoon failliet kunnen gaan. Er kan pas sprake zijn van afwikkeling als, grosso modo, aan een van de vier doelstellingen van afwikkeling zoals genoemd in paragraaf 3.3 is voldaan (waarbij geldt dat het doel van bescherming van polishouders (doelstelling a) altijd in samenhang dient te worden bezien met een van de drie andere doelen, en dus niet het enige doel van afwikkeling kan zijn).

Met de invoering van de algemeen-belangtoets in een concreet geval ligt de lat voor het nemen van een afwikkelingsmaatregel onder het huidige recht naar onze mening aanmerkelijk hoger voor DNB dan onder de oude overdrachtsregeling. Daarbij zou DNB onder het huidige recht vanuit materieel oogpunt

57. Kamerstukken II 2017/18, 34842, 3, p. 17. 58. Kamerstukken II 2017/18, 34842, 3, p. 72. nauwkeurig dienen te motiveren waarom aan de diverse voorwaarden voor het nemen van een afwikkelmaatregel is voldaan, en waarom afwikkeling in het algemeen belang is in het bijzonder.

DNB lijkt nu minder ruime discretionaire ruimte te hebben dan bij het overdrachtsplan onder het oude recht (zoals bevestigd in de Conservatrix-uitspraak). De wetsgeschiedenis van de Whav benadrukt die beleids- en beoordelingsvrijheid namelijk minder nadrukkelijk dan de wetsgeschiedenis van de oude regeling. Daar werd bijvoorbeeld nog gesproken over een 'ruime beoordelingsvrijheid', terwijl de wetsgeschiedenis van de Whav spreekt van 'enige mate van beoordelingsvrijheid'.

Daarnaast, anders dan onder de oude overdrachtsregeling, benadrukt de wetsgeschiedenis van de Whav nu geenszins een summiere, terughoudende, beoordeling van de rechter. De vraag is wel of de rechterlijke toetsing onder het huidige recht veel zal verschillen van de toetsing onder het oude recht (en bij Conservatrix).

\subsection{Rechtsgang}

De rechtsgang ten aanzien van het nemen van een afwikkelingsmaatregel is, zoals hierboven al aangegeven, ingrijpend gewijzigd. Waar DNB onder het oude recht goedkeuring van de rechtbank nodig had voordat een overdrachtsplan überhaupt kon worden ingesteld, is onder de huidige regelgeving een ex-antetoets door de rechter niet meer vereist. DNB heeft hierin dus een volledig zelfstandige bevoegdheid gekregen.

Daardoor heeft ook de civiele rechter geen rol meer bij het nemen van een afwikkelingsmaatregel door DNB. De ex-antetoets door de civiele rechter voor de oude overdrachtsregeling was gespiegeld aan de rechterlijke toets bij een faillissementsprocedure. Vandaar ook het gebruik van het toetsingscriterium 'summierlijk blijken', dat eveneens in art. $6 \mathrm{Fw}$ wordt gebruikt. ${ }^{59}$

Zoals hierboven aangegeven, is de nieuwe ex-postrechtsgang van een besluit van DNB tot het nemen van een afwikkelingsmaatregel door de wetgever, in lijn met de hoofdregel van besluiten van een bestuursorgaan, bij de bestuursrechter belegd. De wetgever licht de keuze voor een rechtsgang bij de bestuursrechter als volgt toe: ${ }^{60}$

'Anders dan bij toepassing van de bevoegdheden ingevolge Deel 3, waarbij een overdrachtsplan ter beoordeling en goedkeuring aan de rechter wordt voorgelegd, is in het kader van Deel 3A sprake van zelfstandige uitoefening van wettelijke bevoegdheden door een bestuursorgaan. Daarbij is bestuursrechtelijke rechtsbescherming het meest aangewezen. $\mathrm{Nu}$ geen sprake is van een ex ante rechterlijke toets, behoeft ook om die reden niet te worden gekozen

59. Kamerstukken II $2011 / 12,33059,3$, p. 54 .

60. Kamerstukken II 2017/18, 34842, 3, p. 30. Zie in vergelijkbare zin ook Kamerstukken I 2017/18, 34842, C, p. 9. 
voor het alternatief van civielrechtelijke rechtsbescherming. Er is ook in dat opzicht geen aanleiding om af te wijken van de hoofdregel dat besluiten van DNB en de AFM door de bestuursrechter worden getoetst. Waar $\mathrm{DNB}$, en voor zover van toepassing de AFM, besluiten neemt, zijn de Wft, de Algemene wet bestuursrecht (Awb) en de algemene beginselen van behoorlijk bestuur relevant.'

Daarvoor is weer wel een van de normale procedure afwijkende bestuursrechtelijke rechtsgang gekozen. Tegen een afwikkelingsbesluit kan rechtstreeks beroep worden ingesteld bij het $\mathrm{CBb}$. Daarmee worden de bezwaarfase en het beroep bij de Rechtbank Rotterdam overgeslagen. Ook geldt er een verkorte termijn voor het instellen van beroep van tien dagen na het afwikkelingsbesluit. $\mathrm{Na}$ afloop van de termijn voor het instellen van beroep kunnen geen beroepsgronden meer worden aangevoerd. Het $\mathrm{CBb}$ dient uiterlijk veertien dagen na het instellen van beroep uitspraak te doen. ${ }^{61}$

Volgens de wetgever is voor deze bijzondere versnelde rechtsgang gekozen omdat een afwikkelingsbesluit een ingrijpend karakter heeft en snel leidt tot onomkeerbare gevolgen. Daardoor is een snel en definitief rechterlijk oordeel over de rechtmatigheid van het afwikkelingsbesluit wenselijk. Deze snelle procedure komt volgens de wetgever de rechtszekerheid ten goede. ${ }^{62}$

De rechtszekerheid is verder gewaarborgd doordat, zoals gebruikelijk in het bestuursprocesrecht, een eventueel beroep bij het $\mathrm{CBb}$ de werking van het afwikkelingsbesluit niet schorst. ${ }^{63}$ Hangende het beroep kan aan het $\mathrm{CBb}$ worden verzocht een voorlopige voorziening te treffen. De Whav bepaalt echter expliciet bij een dergelijk verzoek dat het afwikkelingsbesluit tot het weerlegbare rechtsvermoeden (en dus omkering van de bewijslast) leidt dat opschorting ervan indruist tegen het algemeen belang. ${ }^{64}$ Tot slot, als het $\mathrm{CBb}$ het beroep gegrond acht, kan het een door DNB genomen afwikkelingsmaatregel vernietigen. Daarbij kan het $\mathrm{CBb}$ met het oog op de rechtszekerheid wel bepalen dat de rechtsgevolgen van het vernietigde besluit geheel of gedeeltelijk in stand blijven. Dit kan het $\mathrm{CBb}$ doen als dit noodzakelijk is ter bescherming van de belangen van te goeder trouw handelende derden die door het besluit eigendomsinstrumenten, activa, rechten of passiva van de entiteit in afwikkeling hebben verkregen (bijvoorbeeld de overnemende partij). ${ }^{65}$

Dat betekent concreet dat zelfs als het $\mathrm{CBb}$ al tot de conclusie komt dat het beroep van de onteigende aandeelhouder gegrond is, dit in feite een pyrrusoverwinning is. De Serière merkt op dat in een dergelijk geval voor de benadeelde een

61. Art. 3a: $135 \mathrm{Wft}$.

62. Kamerstukken II $2017 / 18,34842,3$, p. 31.

63. Art. 6:16 Awb

64. Art. 8:81 Awb en art. 3a:136 Wft.

65. Art. 3a:137 Wft en art. 8:72 lid 3 Awb. schadevergoedingsprocedure onder het gemene recht over zou blijven, nu de Whav hier niets concreets over regelt. Wij vragen ons daarbij wel af wie de benadeelde hier met succes zou kunnen aanspreken. DNB aanspreken zal, gelet op de aansprakelijkheidsuitsluiting voor DNB op grond van art. 1:25d Wft, in elk geval nagenoeg onmogelijk zijn. Hierbij kan nog wel het NCWO-beginsel van belang zijn (zie par. 4.4 hieronder).

De keuze voor de standaard van een bestuursrechtelijke rechtsgang bij een autonoom besluit van DNB kunnen wij goed volgen. Ook het belang dat wordt gehecht aan een snelle procedure en rechtszekerheid zien wij. Twijfel in de markt over het al dan niet doorgaan van de overname als gevolg van het afwikkelingsmechanisme is - gelet op het verlammende effect daarvan en de doelstelling nu juist de stabiliteit van het financiële stelsel te waarborgen - erg onwenselijk. Wel delen wij de zorg van De Serière over de korte beroepstermijnen. ${ }^{66}$

Los van de vraag naar het resultaat van een geslaagde beroepsprocedure tegen een afwikkelingsbesluit van DNB, blijft de vraag van groot belang wat voor een toets het $\mathrm{CBb}$ kan toepassen ten aanzien van het besluit van DNB. Uit de Conservatrix-uitspraak bleek dat de rechtbank onder het oude recht het verzoek tot het goedkeuren van het overdrachtsplan slechts 'summierlijk' (en daarmee marginaal) diende te beoordelen. Zoals eerder gezegd, de tekst en de wetsgeschiedenis van de huidige Whav schrijven nu niet langer expliciet een summierlijke toets voor. De belangrijkste opmerkingen in de wetsgeschiedenis in dit kader zijn de opmerkingen dat waar DNB een besluit neemt de algemene beginselen van behoorlijk bestuur van toepassing zijn, en dat DNB enige mate van beoordelingsvrijheid heeft bij haar oordeel of afwikkeling in het algemeen belang is.

Gelet op het feit dat hier voor de standaard bestuursrechtelijke rechtsgang en daarmee toetsing is gekozen, is onze verwachting dat het $\mathrm{CBb}$ desondanks niet veel voller zal toetsen dan de summiere toets die de civiele rechter uitvoerde ten aanzien van het oude overdrachtsplan. Immers, zoals hierboven al aangegeven, krijgt DNB op grond van de Whav enige discretionaire bevoegdheid om te besluiten of in een concreet geval afwikkeling in het algemeen belang is, en al dan niet te besluiten om over te gaan tot afwikkeling van een verzekeraar. Weliswaar dient DNB een aantal voorwaarden te toetsen voor zij tot afwikkeling mag besluiten, maar zij heeft daarbij dus wel 'enige mate van beoordelingsvrijheid'. Van een gebonden bevoegdheid van DNB lijkt in die zin dan ook geen sprake. Het feit dat het besluit om tot afwikkeling over te gaan een imperatief karakter kent (als aan de drie voorwaarden (falen of waarschijnlijk zullen falen, geen alternatieve oplossing voorhanden en in het algemeen belang) wordt voldaan, moet DNB tot afwikkeling overgaan), doet hieraan niet af; het gaat erom dat DNB bij de beoordeling of afwikkeling in een concreet

66. V.P.G. de Serière, annotatie bij HR 17 mei 2019, ECLI:NL:HR: 2019:746, NJ 2019/389, randnr. 8. 


\section{Maandblad}

geval in het algemeen belang is een zekere mate van beoordelingsvrijheid toekomt.

Naar regulier bestuursrecht zal een bestuursrechter de wijze waarop DNB in een concreet geval van haar discretionaire bevoegdheid gebruik heeft gemaakt marginaal toetsen. Dat komt neer op de vraag of het orgaan in redelijkheid tot zijn oordeel heeft kunnen komen. ${ }^{67}$ Daarbij dienen in principe wel de algemene beginselen van behoorlijk bestuur, zoals het motiveringsbeginsel en het evenredigheidsbeginsel, te worden meegenomen. De vraag is alleen wat de intensiteit van die marginale toetsing door de rechter aan de hand van de algemene beginselen van behoorlijk bestuur is. ${ }^{68}$

In onze ervaring stelt de financieelrechtelijke bestuursrechter zich over het algemeen terughoudend op bij de toetsing van besluiten van DNB die voortkomen uit een discretionaire bevoegdheid van DNB. Naar onze mening zou onder andere vanwege de autonome bevoegdheid van DNB, de expliciete verplichting proportionaliteit en het algemeen belang mee te nemen in de besluitvorming, en de zeer indringende en vrijwel onomkeerbare rechtsgevolgen van een afwikkelingsbesluit wel een extra verantwoordelijkheid op DNB moeten rusten om haar afwikkelingsbesluit zorgvuldig te nemen. ${ }^{69}$ Of de bestuursrechter in lijn daarmee bijvoorbeeld hogere motiveringsstandaarden eist of intensiever zal toetsen, is voorlopig maar zeer de vraag.

\subsection{No creditor worse off}

Tot slot is een belangrijk verschil tussen de oude overdrachtsregeling en de huidige afwikkelingsregels het samenspel van de afwikkeling ten opzichte van faillissement. Met name het in de Whav verankerde NCWO-beginsel is in dat kader van belang. ${ }^{70} \mathrm{Het}$ NCWO-beginsel bestond voor verzekeraars nog

67. Zie L.J.A. Damen, Bestuursrecht, Den Haag: Boom juridisch 2019, p. 315-316.

68. Wij merken op dat de intensiteit van toetsing door de bestuursrechter momenteel een belangrijk onderwerp van discussie in de literatuur is. Daarbij wordt gesignaleerd dat een standaard terughoudend toetsen zodra sprake is van ruime bestuursbevoegdheden langzamerhand plaats begint te maken voor een toetsing op maat met gebruikmaking van het evenredigheidsbeginsel. Dat juichen wij zeer toe. Zie in dit kader bijv. T. Barkhuysen \& W. den Ouden, Kroniek van het algemeen bestuursrecht. Over integrale geschilbeslechting, de opmars van het evenredigheidsbeginsel en voortschrijdende Europeanisering, NJB 2018, afl. 15, p. 1006-1007, R. Ortlep \& W. Zorg, Van marginale rechterlijke toetsing naar toetsing op maat: einde van een geconditioneerde respons?, AA 2018, afl. 1, p. 25 en R.J.N. Schlössels, Beginselen van behoorlijk bestuur, NTB 2019/42, p. 434.

69. Dat de wetgever op meerdere plaatsen in de MvT aangeeft dat de afwikkelingsbevoegdheden te allen tijde proportioneel toegepast dienen te worden, is wat ons betreft in principe het bevestigen van het op grond van art. 3:4 Awb geldende evenredigheidsbeginsel. Toch houdt het feit dat de wetgever dit beginsel hier nog extra benadrukt, wat ons betreft wel een opdracht aan de toezichthouder in.

70. Art. 3a: $88 \mathrm{Wft}$. Verder zijn tegelijkertijd met de invoering van de Whav enkele nieuwe bevoegdheden aan de curator in faillissement gegeven. Zo kan de curator (voor bepaalde verzekeringen) al uitkeringen doen voordat de verificatievergadering heeft plaatsgevonden (art. 213ma Fw). Op deze en overige specifieke nadere Fw-bepalingen als gevolg van de Whav gaan wij in dit artikel verder niet in. niet ten tijde van de oude overdrachtsregeling die in de Conservatrix-zaak is gebruikt. ${ }^{71} \mathrm{~W}_{\mathrm{ij}}$ bespreken dat beginsel hieronder kort.

Zoals hierboven aangegeven, is onder de huidige regelgeving het faillissement van een verzekeraar expliciet de default, en een afwikkeling door DNB een uitzondering. ${ }^{72}$ In verband hiermee mogen bij toepassing van een afwikkelingsinstrument de aandeelhouders en schuldeisers van de verzekeraar geen grotere verliezen lijden dan wanneer de verzekeraar onmiddellijk daaraan voorafgaand conform de normale procedure in de Fw zou zijn geliquideerd. Dit begrenst volgens de wetgever de vrijheid van DNB om tot afwikkeling over te gaan, en de mogelijkheden om vorderingen ongelimiteerd af te schrijven of de waarde te bepalen van overgedragen activa of passiva. ${ }^{73}$

Naar onze mening zou het NCWO-beginsel tot een extra motiveringsverplichting van DNB moeten leiden, voordat zij een afwikkelingsbesluit neemt. Als het NCWO-beginsel is geschonden, tast dat echter niet de rechtmatigheid van het afwikkelingsbesluit aan. De vraag is dan ook of het CBb bij zijn toets ten aanzien van het afwikkelingsbesluit, het NCWO-beginsel betrekt. Bij een eventuele schending van het NCWO-beginsel is de vraag namelijk primair in hoeverre een recht bestaat op schadeloosstelling. Als uit de ex-postwaardering blijkt dat een houder van eigendomsinstrumenten of een schuldeiser van de verzekeraar grotere verliezen heeft geleden dan hij zou hebben geleden in faillissement, kent DNB een vergoeding toe. ${ }^{74}$ Ten aanzien van dat schadevergoedingsbesluit van DNB staat de normale bestuursrechtelijke rechtsgang open. $^{75}$

\section{Conclusie}

De overdrachtsregeling, het onderwerp van de Conservatrixuitspraak, is niet meer. Daarvoor in de plaats is het afwikkelinstrumentarium voor verzekeraars van de Whav gekomen. De Whav is op veel punten wezenlijk anders dan de oude overdrachtsregeling, en heeft grote gevolgen voor verzekeraars. De vraag is of de huidige regelgeving aandeelhouders van een verzekeraar in moeilijkheden meer bescherming biedt.

Een interessante vraag is bijvoorbeeld of Conservatrix, als deze casus zich onder de Whav had voorgedaan, wel zou zijn afgewikkeld (de uitzonderingssituatie), of dat DNB zou hebben besloten haar te laten failleren en te liquideren (de default). Wij zijn van mening dat het voor de hand ligt dat DNB onder het huidige recht op grond van het algemeen-belangcriterium zou hebben besloten dat Conservatrix failliet diende te wor-

71. De oude overdrachtsregeling bevatte wel art. 3:159ij lid 3 (oud) Wft. Op grond van dat lid keurde de rechtbank het overdrachtsplan met betrekking tot activa of passiva goed, tenzij schuldeisers daardoor zouden worden benadeeld. Deze bepaling zag slechts op een overdracht van activa en passiva en maakte geen expliciete vergelijking met faillissement.

72. Kamerstukken II $2017 / 18,34842,3$, p. 73.

73. Kamerstukken II 2017/18, 34842, 3, p. 91

74. Art. 3a:91 lid $4 \mathrm{Wft}$.

75. Kamerstukken II 2017/18, 34842, 3, p. 73. 


\section{Maandblad} Vermogensrecht

den verklaard. Het is in onze optiek bepaald niet evident welk algemeen belang afwikkeling door DNB zou rechtvaardigen. Conservatrix is een kleine levensverzekeraar, die bovendien geen nieuwe business meer genereert (zij onderhoudt uitsluitend een closed book). Uit de wetsgeschiedenis blijkt dat afwikkeling voor (middel)grote verzekeraars ( $>1$ miljoen polishouders of $>€ 1$ miljard aan technische voorzieningen) in elk geval in de rede ligt. Conservatrix' omvang komt hierbij niet eens in de buurt. ${ }^{76}$

Wij zouden menen dat onder de Whav de drempel voor DNB om tot afwikkeling te besluiten hoger is dan onder de overdrachtsregeling en de Conservatrix-uitspraak het geval was. Wij verwachten dat met name de algemeen-belangtoets die DNB in een concreet geval zal moeten uitvoeren alvorens tot afwikkeling te kunnen besluiten, en het NCWO-beginsel veel vaker in faillissement zullen resulteren dan in afwikkeling. Mocht het toch tot een afwikkelingsbesluit komen, dan verwachten wij dat de toets die de bestuursrechter (het $\mathrm{CBb}$ ) op het afwikkelingsbesluit van DNB zal toepassen - zoals bij de Conservatrix-uitspraak - een marginale toets zal zijn.

Overigens, uit de pers lijkt het na de overname door Trier/Eli Global niet navenant beter te zijn gegaan met Conservatrix. ${ }^{77}$ Conservatrix staat weer te koop, en van een nieuwe koper wordt wederom verwacht dat hij flink wat eigen vermogen meebrengt.

76. Uit Conservatrix' Annual Report 2018 blijkt bijv. dat de technische voorzieningen van Conservatrix op 31 december 2017 ca. $€ 516$ miljoen bedroegen.

77. O.m. Het Financieele Dagblad 2 september 2019, 'Geredde' verzekeraar Conservatrix weer te koop. 